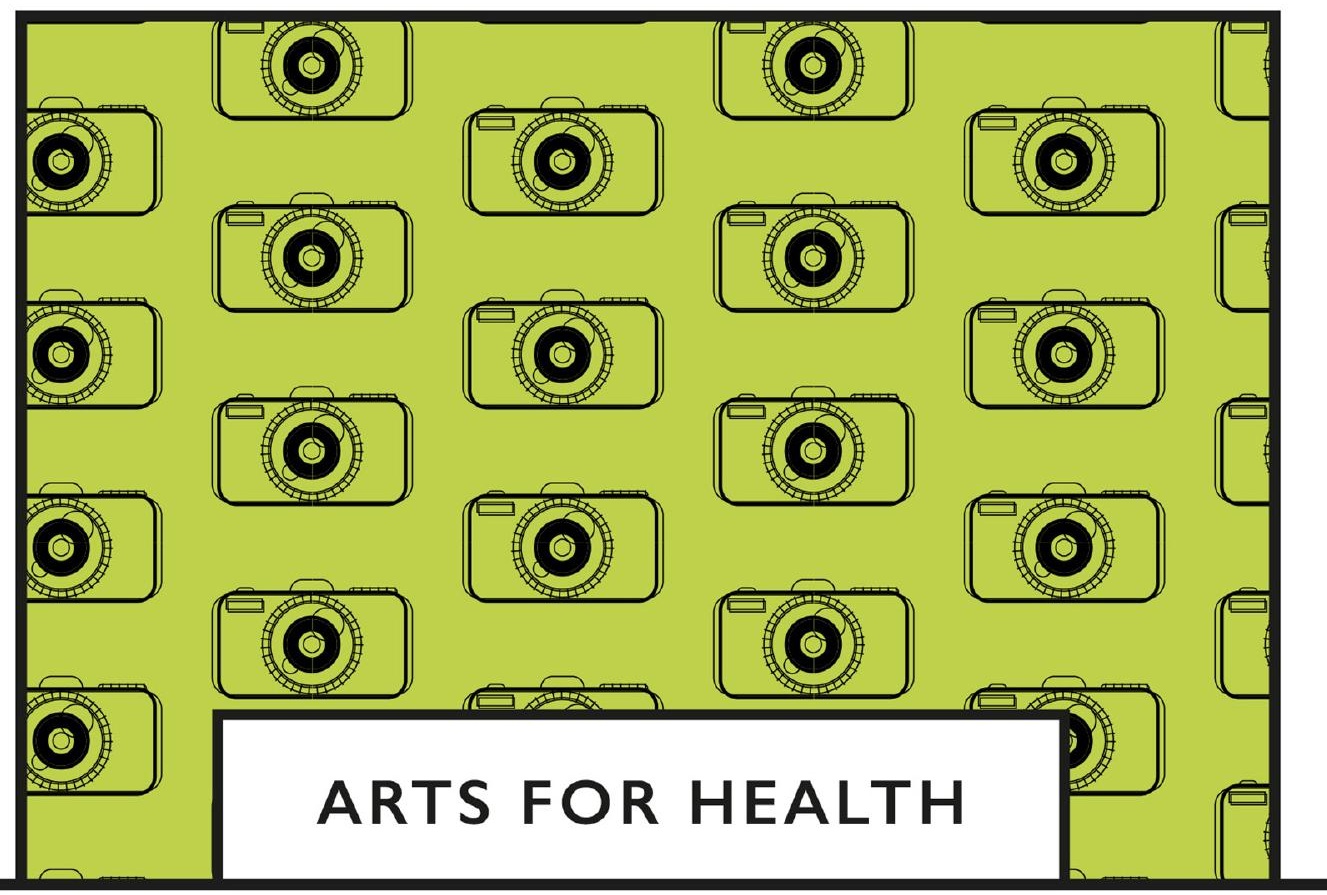

\title{
PHOTOGRAPHY
}

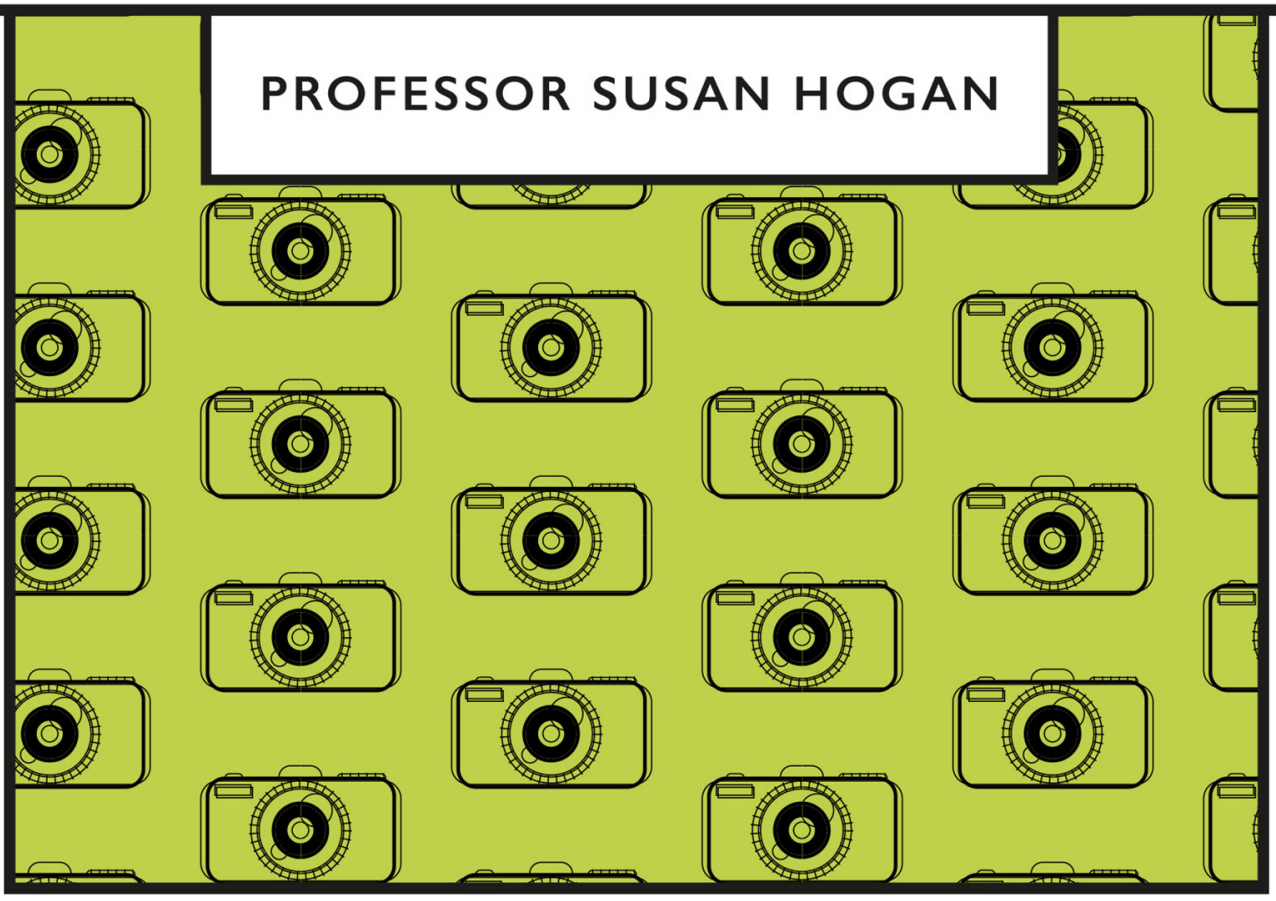


PHOTOGRAPHY 


\section{ARTS FOR HEALTH}

Series Editor: Paul Crawford, Professor of Health Humanities, University of Nottingham, UK

The Arts for Health series offers a ground-breaking set of books that guide the general public, carers and healthcare providers on how different arts can help people to stay healthy or improve their health and wellbeing.

Bringing together new information and resources underpinning the health humanities (that link health and social care disciplines with the arts and humanities), the books demonstrate the ways in which the arts offer people worldwide a kind of shadow health service - a non-clinical way to maintain or improve our health and wellbeing. The books are aimed at general readers along with interested arts practitioners seeking to explore the health benefits of their work, health and social care providers and clinicians wishing to learn about the application of the arts for health, educators in arts, health and social care and organisations, carers and individuals engaged in public health or generating healthier environments. These easy-to-read, engaging short books help readers to understand the evidence about the value of arts for health and offer guidelines, case studies and resources to make use of these nonclinical routes to a better life.

Other titles in the series:

$\begin{array}{ll}\text { Film } & \text { Steven Schlozman } \\ \text { Theatre } & \text { Sydney Cheek-O’Donnell } \\ \text { Singing } & \text { Yoon Irons and Grenville Hancox } \\ \text { Music } & \text { Eugene Beresin } \\ \text { Dancing } & \text { Sara Houston } \\ \text { Drawing } & \text { Curie Scott } \\ \text { Storytelling } & \text { Michael Wilson }\end{array}$




\title{
PHOTOGRAPHY
}

\author{
SUSAN HOGAN
}

\section{emerald PUBLISHING}

United Kingdom - North America - Japan - India

Malaysia - China 
Emerald Publishing Limited

Howard House, Wagon Lane, Bingley BD16 1WA, UK

First edition 2022

Copyright (C) 2022 Susan Hogan.

Published under exclusive licence by Emerald Publishing Limited.

\section{Reprints and permissions service}

Contact: permissions@emeraldinsight.com

No part of this book may be reproduced, stored in a retrieval system, transmitted in any form or by any means electronic, mechanical, photocopying, recording or otherwise without either the prior written permission of the publisher or a licence permitting restricted copying issued in the UK by The Copyright Licensing Agency and in the USA by The Copyright Clearance Center. No responsibility is accepted for the accuracy of information contained in the text, illustrations or advertisements. The opinions expressed in these chapters are not necessarily those of the Author or the publisher.

\section{British Library Cataloguing in Publication Data}

A catalogue record for this book is available from the British Library

ISBN: 978-1-80071-538-7 (Print)

ISBN: 978-1-80071-535-6 (Online)

ISBN: 978-1-80071-537-0 (Epub)

ISOQAR certified 


\section{CONTENTS}

List of Illustrations viii

Series Preface: Creative Public Health xii

1. Introduction 1

> Background 1

> Aims and Scope 2

> Why Discuss Photography? 3

> Content 3

2. A Brief Summary of the History and Development of Photography 7

> Photography of the Natural World 7

> Architectural and Landscape Photography 14

> Photographic Portraiture and Carte de Visites 18

> Photojournalism 24

> Documentary Photography 27

> Photography in Anthropology 39

> Photography as Art 43

> The Rise of the Family Album 46

> Digital Photography and the Rise of Social

> Selfies and Digital Realism 55

3. How Are Photographs Distinctive? 57

> Ways of Seeing 58

> Objectification 61

> Word and Text 68

> Polysemy 73

> Verisimilitude 78 
4. Photographic Practice for Health and Wellbeing 81

> Photography for Pleasure 81

> Satisfaction With Content and Composition 84

> Portraiture and Self-portraiture 86

> Photography in Health Promotion and Social Care

> Documentary Photography for Health and Wellbeing 91

> Photography as Art Practice 93

> Photography to Empower Communities and Communities of Interest

5. Photography in Research (Summary of Photographic Research Methods: Photo-documentation, Photoelicitation, Semiotic Analysis and Content Analysis)

> Who Can Benefit?

> Summary of Photographic Research Methods

> What Helps? Photo-documentation, Photo-elicitation and Semiotic Analysis $\quad 115$

> Photo-documentation

> Photo-elicitation

$>$ Photo Diaries

> A Semiotic Analysis

$>$ Content Analysis

$>$ Discussion

6. An Introduction to Re-enactment Phototherapy

> Antecedents and Evolution of Re-enactment Phototherapy

> Re-enactment Phototherapy in Practice

> The Re-enactment Phototherapy Technique

7. Therapeutic Photography

> Therapeutic Photography or Phototherapy?

> Photography Within Art Therapy 156

> Therapeutic Photography 158

> Therapeutic Photography in Practice 159

> Photography as Part of Projective Processes 159

> Self-portrait Therapeutic Photography 166 
> Photographs Made by Others

> Using Photographs in Metaphoric Ways to Think about Selfhood

> Therapeutic Photography in Relation to Photo Systems

Suggestions for Further Reading

Notes

Bibliography

197

Acknowledgements

213

Index 


\section{LIST OF ILLUSTRATIONS}

Fig. 1. Digital Collection New York Public Library. Photographs of British Algae: Cyanotype Impressions. Anna Atkins. c. 1843-1850.b. This example c. 1850.

Fig. 2. Leonine Specimens: Illustration in Giambattista della Porta's De Humana Physiognomia (Naples, 1602). The Getty Research Institute, Los Angeles 2934-552.

Fig. 3. Power House Mechanic 1921. Lewis Wickes Hine (United States 1874-1940) Power House Mechanic 1921. Part of the Men at Work 1920-1940 Dignity of Labour Series. () Brooklyn Museum, Gift of Walter and Naomi Rosenblum, Gelatin silver photograph.

Fig. 4. Edith Tudor Hart, Pater Ferris Wheel in Vienna c. 1930 National Galleries Scotland. (C) Held jointly by Peter Suschitzky, Julia Donat and Misha Donat. Reproduced with kind permission from the Tudor Hart Estate.

Fig. 5. Typologies, Water Towers. 1972-2009. Hilla and Bernd Becher. Dimensions: Displayed: 1,720 × $1,420 \times 21 \mathrm{~mm}$. (C) Estate of Bernd Becher and Hilla Becher. (Image ID \#: P81238. Accession \#: P81238).

Fig. 6. lago, Study from an Italian. Julia Margaret Cameron, 1867. () Creative Commons Licence.

Fig. 7. Bathwomb 2005. () Eti Wade. Reproduced with kind permission of Eti Wade.

Fig. 8. Dow Wasiksiri. It's Plastic But Trust Me 2013 (Conversation with the Past Series) 2209 Gallery Singapore. Colour Photograph. () Dow Wasiksiri. Based on Unknown, 'Studio Portrait of a Javanese 
Woman Fruit Seller' c. 1870-1900, Tropenmuseum, Amsterdam. Produced with kind permission of Dow Wasiksiri.

Fig. 9. Close, No. 65 High Street by Thomas Annan.

(c) Getty open content.

Fig. 10. Child Staring into a Bakery Window, Whitechapel, 1935 (Courtesy of National Gallery of Scotland) Poverty in London by Edith Tudor Hart. (C) Held jointly by Peter Suschitzky, Julia Donat and Misha Donat. Reproduced with kind permission from the Tudor Hart Estate.

Fig. 11. Fritz Klein, The Camp Doctor, Standing in a Mass Grave at Bergen-Belsen after the Camp's Liberation by the British 11th Armoured Division, April 1945. (c) Public domain.

Fig. 12. A View of the Ceiling at the Hall of Names at the Yad Vashem Holocaust Memorial Museum in Jerusalem. International Holocaust Remembrance Day on January 27. Photograph: (C Ludovic Marin/AFP via Getty Images open content royalty free.

Fig. 13. Nick Ut, The terror of War 1972 - () Creative Commons.

Fig. 14. Migrant Mother by Dorothea Lange 1936.

(C) Creative Commons.

Fig. 15. Holiday Makers. Neil Bailey 2019. Original in Colour. Reproduced with kind permission from Neil Bailey.

Fig. 16. Hengameh Golestan b. 1952. Untitled from the Witness 1979 Series, March, Tehran (C) Hengameh Golestan, Courtesy of Archaeology of the Final Decade. Original in Colour.

Fig. 17. Maia Biala, the Chief of Rultland Island with This Wife. 4 May 1872. Photograph by G. E. Dobson. Courtesy of Oxford, Pitt Rivers Museum.

Fig. 18. Sweetness and Light, 1996 by Roshini Kempadoo.

Original in Colour. (C) Reproduced with kind permission of Roshini Kempadoo. 
Fig. 19. Shadafarin Ghadirian b. 1974 Untitled 2000. (C) Shadafarin Ghadirian. Reproduced with kind permission from Shadafarin Ghadirian.

Fig. 20. A Nursery Is My Right. Hackney Flashers.

Undated (C) 1978. Courtesy of the Hackney

Flashers Archive, Bishopsgate Institute.

Fig. 21. Jo Spence in Collaboration with Rosy Martin Libido Uprising 1989. Installation. Colour Photograph (C) Original in colour. Reproduced with kind permission from Ryerson Image Centre \& Rosy Martin.

Fig. 22. Jo Spence in Collaboration with Rosy Martin Libido Uprising 1989. Detail. Colour Photograph (c) Reproduced with kind permission from Ryerson Image Centre \& Rosy Martin.

Fig. 23. Boushra Almutaeakel Mother, Daughter, Doll 2010. (Original in Colour). (C) Boushra Almutaeakel. Reproduced with kind permission from Boushra Almutaeakel.

Fig. 24. Boushra Almutaeakel The Hijab Series:

What If? 2008. (C) Boushra Almutaeakel. Reproduced with kind permission from Boushra Almutaeakel. 105

Fig. 25. Gerry and Friend at 3425 Stanley, from the series, Friends and Lovers: Coming out in the 70's, Montreal 1972. Sunil Gupta. Image Courtesy the Artist and Hales Gallery, Stephen Bulger Gallery and Vadehra Art Gallery. (c) Sunil Gupta.

All Rights Reserved, DACS 2021.

Fig. 26. Tessa Boffin, 'The Angel', from the Series 'The Knight's Move' (c) Tessa Boffin 1990. Courtesy of the Estate of Tessa Boffin/ Gupta+Singh Archives, London 2021.

Fig. 27. Della Grace. The Ceremony, Peri \& Robyn, London 1988 Credit: (aka Del LaGrace Volcano). 109

Fig. 28. (Pair of Images). Landslip and Land Problems at the Creek, 1999. ( B Beilin. Originally Published in Looking for Landcare, PhD Thesis RMIT. Reproduced with kind permission from Ruth Beilin. 
Fig. 29. Achetez des Pommes (Anonymous Nineteenth Century) Juxtaposed with Achetez des Bananes by Linda Nochlin. (C) Linda Nochlin - Courtesy the Estate of Linda Nochlin. 


\section{SERIES PREFACE: CREATIVE PUBLIC HEALTH}

The 'Arts for Health' series aims to provide key information on how different arts and humanities practices can support, or even transform, health and wellbeing. Each book introduces a particular creative activity or resource and outlines its place and value in society, the evidence for its use in advancing health and wellbeing, and cases of how this works. In addition, each book provides useful links and suggestions to readers for following-up on these quick reads. We can think of this series as a kind of shadow health service encouraging the use of the arts and humanities alongside all the other resources on offer to keep us fit and well.

Creative practices in the arts and humanities offer a fantastic, non-medical, but medically relevant way to improve the health and wellbeing of individuals, families and communities. Intuitively, we know just how important creative activities are in maintaining or recovering our best possible lives. For example, imagine that we woke up tomorrow to find that all music, books or films had to be destroyed, learn that singing, dancing or theatre had been outlawed or that galleries, museums and theatres had to close permanently; or, indeed, that every street had posters warning citizens of severe punishment for taking photographs, drawing or writing. How would we feel? What would happen to our bodies and minds? How would we survive? Unfortunately, we have seen this kind of removal of creative activities from human society before and today many people remain terribly restricted in artistic expression and consumption.

I hope that this series adds a practical resource to the public. I hope people buy these little books as gifts for family and friends, or for hard-pressed healthcare professionals, to encourage them to revisit or to consider a creative path to living well. I hope that creative public health makes for a brighter future. 